\title{
Application of E-Marketing Concept to Analyze Distribution Channel Optimization (Case Study: Frisian Flag Indonesia)
}

\author{
$1^{\text {st }}$ Elpawati $^{1}, 2^{\text {nd }}$ Yunita Chairani Damanik ${ }^{1}, 3^{\text {rd }}$ Rizki Adi Puspitasari $^{1}, 4^{\text {th }}$ Herlino \\ Nanang $^{2}, 5^{\text {th }}$ Nidaul Hasanati ${ }^{2}$ \\ \{elpawati@uinjkt.ac.id ${ }^{1}$,yunita.damanik@mhs.uinjkt.ac.id¹, rizki.adi.puspita@uinjkt.ac.id ${ }^{1}$ \}
}

UIN Syarif Hidayatullah, Department of Agribusiness, Jakarta ${ }^{1}$, UIN Syarif Hidayatullah, Department of Informatics, Jakarta ${ }^{2}$

\begin{abstract}
Milk is one of the essential products for human kind in livestock. Demand of milk products in Indonesia is increasing time to time. Meanwhile, milk supply has not met its requirements. Distribution system in PT Frisian Flag Indonesia is indirect distribution. PT Frisian Flag Indonesia uses intermediary company, namely Yap Cwee Hock ( $\mathrm{YCH}$ ) as Main Distribution Center (MDC). According to level of distribution channel, PT Frisian Flag Indonesia uses distribution channels of Producer-Distributor Industry-Customer. PT Frisian Flag Indonesia has four main Plants, i.e. Plant Pasar Rebo, Plant Ciracas, and MDC Cibitung with its two Plants (MDC for powdered milk and MDC for condensed milk). To optimize product and marketing distribution and integrate each division, so e-marketing system is implemented.
\end{abstract}

Keywords: Distribution, Distribution Channel, E-Marketing, PT Frisian Flag Indonesia

\section{Introduction}

Demand of milk products in Indonesia is increasing time to time. Meanwhile, milk supply has not met its requirements. This situation opens the challenge for milk products in Indonesia to increase the growth of industry to meet the requirements of milk products both in regional and national scale. Milk industry in Indonesia is one of the strategic and potential food industries for entrepreneurs. PT Frisian Flag Indonesia is one of milk producers in Indonesia.

Distribution is marketing process that aims to produce added value of products through marketing purposes in achieving utilizations, forms, time and ownership, as well as products distributions or services from producer to consumer [1].

PT Frisian Flag Indonesia uses indirect distribution system, namely distribution or products sell/service through intermediary company, which leads to quite expensive cost of distribution. PT Frisian Flag Indonesia has two factories, i.e. Plant Pasar Rebo and Plant Ciracas. In optimizing distribution channels and minimizing distribution costs, the company is supposed to optimize distribution channels and minimize distribution cost to maximize products transported. This research aimed to: 1) Discover actual distribution systems in PT Frisian Flag Indonesia. 2) Analyze the distribution channel allocations and the optimal product volume in PT Frisian Flag Indonesia, from origin to destination. 3) Analyze the managerial 
implications on milk distributions in PT Frisian Flag Indonesia, based on the optimization of distribution channels.

\section{Theoretical Framework}

Marketing is the process of social and managerial, which includes individual and groups to achieve their needs by creating, offering, and exchanging valuable products with other parties [2].

E-marketing strategies need utilizing existing and emerging communication and data networks to give personalized and uninterrupted communication between the firm and its customers and to provide value above traditional networks [3].

Matrix on the solution of transportation problems is shown as follows:

Table 1. Startup Matrix Onthe Solution Of Transportation Problem (Source: Aminudin, 2005) [4]

\begin{tabular}{|c|c|c|c|c|c|c|c|c|}
\hline & \multicolumn{6}{|c|}{ Destination } & \multirow{2}{*}{$\begin{array}{c}\text { Total } \\
\text { Demand }\end{array}$} \\
\hline & & 1 & 2 & 3 & 4 & 5 & 6 & \\
\hline $\mathrm{O}$ & \multirow{4}{*}{1} & $\mathrm{C}$ & $\mathrm{C}$ & $\mathrm{C}$ & $\mathrm{C}$ & $\mathrm{C}$ & $\mathrm{C}$ & \multirow{4}{*}{ a1 } \\
\hline $\mathrm{r}$ & & 11 & 11 & 11 & 11 & 11 & 11 & \\
\hline $\mathrm{i}$ & & & & & & & & \\
\hline g & & X11 & $\mathrm{X} 12$ & X13 & X14 & X15 & X16 & \\
\hline $\mathrm{i}$ & \multirow{3}{*}{2} & $\mathrm{C}$ & $\mathrm{C}$ & $\mathrm{C}$ & $\mathrm{C}$ & $\mathrm{C}$ & $\mathrm{C}$ & \multirow{3}{*}{$\mathrm{a} 2$} \\
\hline $\mathrm{n}$ & & 11 & 11 & 11 & 11 & 11 & 11 & \\
\hline & & $\mathrm{X} 21$ & $\mathrm{X} 22$ & X23 & X24 & $\mathrm{X} 25$ & X26 & \\
\hline $\begin{array}{c}\text { A } \\
r\end{array}$ & \multirow{3}{*}{3} & \begin{tabular}{|l|}
$\mathrm{C}$ \\
11
\end{tabular} & \begin{tabular}{|l|}
$\mathrm{C}$ \\
11
\end{tabular} & \begin{tabular}{|l|}
$\mathrm{C}$ \\
11
\end{tabular} & \begin{tabular}{|l|}
$\mathrm{C}$ \\
11
\end{tabular} & \begin{tabular}{|l|}
$\mathrm{C}$ \\
11
\end{tabular} & \begin{tabular}{|l|}
$\mathrm{C}$ \\
11
\end{tabular} & \multirow{3}{*}{ a3 } \\
\hline e & & & & & & & & \\
\hline $\mathrm{a}$ & & $\mathrm{X} 31$ & X32 & X33 & X34 & $\mathrm{X} 35$ & $\mathrm{X} 36$ & \\
\hline \multicolumn{2}{|c|}{$\begin{array}{c}\text { Total } \\
\text { Supply }\end{array}$} & b1 & b2 & b3 & b4 & b5 & b6 & $a i=b i$ \\
\hline
\end{tabular}

According to [5], distribution channel is a product of distribution that used by producer to distribute products from producer to consumer or industries.

Optimization is a series of process to achieve the best result in certain circumstances. Normative approaches may discover optimization to identify the best solution in solving problems, which involve maximization or minimization objectives through the objective function [6].

According to [7] transportation model is a part of Linear Programming that is used to organize and distribute sources in delivering products to the needy places to achieve the efficiency of transportation cost.

According to the table above, total cost needed to distribute a unit of product or goods from origin 1 to 1 destination (X11) is $\mathrm{C} 11$.

Objective function on formulation of transportation model is to minimize the total supply and distribution costs from production areas to various destinations by observing various 
constraints, such as delivered products problems, the amount of received products and nonnegative variables.

E-marketing uses the internet as a platform that allows firms to adapt to the needs of customers, reduces transaction costs, and allows customers to move from time- and locationbased behaviors toward non-temporal and non-locational behaviors [3].

There are three main components in Linear Programming, i.e. decision variables, objective function, and constraints. Decision variables are the components of problems that can be handled by decision makers. Objective function is the function to illustrate the objective in linear programming problems that is linked with the optimum arrangement of sources to achieve maximum benefit or minimum cost that will be used. Meanwhile, constraints are mathematical function to limits either minimum or maximum objective value that will be optimally allocated in various available activities or constraints on available alternative actions.

In general, Linear Programming can be illustrated as follows:

Objective Function:

Maks/Min Z $=\mathrm{C}_{1} \mathrm{X}_{1}+\mathrm{C}_{2} \mathrm{X}_{2}+\ldots \ldots .+\mathrm{C}_{\mathrm{j}} \mathrm{X}_{\mathrm{j}}$

Contraints Function:

$$
\begin{aligned}
& a_{11} X_{1}+a_{12} X_{2}+\ldots .+a_{i j} X_{j} \leq \text { or } \geq b_{1} \\
& a_{21} X_{1}+a_{22} X_{2}+\ldots . .+a_{2 j} X_{j} \leq \text { or } \geq b_{1} \\
& a_{i 1} X_{1}+a_{i 2} X_{2}+\ldots .+a_{i j} X_{j} \leq \text { or } \geq b_{i} \\
& X_{1}, X_{2, \ldots .,} X_{j} \leq \text { or } \geq 0
\end{aligned}
$$

Where:

$\mathrm{Z}$ = scale value of decision making to maximize/minimize objective function

$\mathrm{Cj}=$ parameter as the optimal criteria and coefficient of decision making change in objective function

$\mathrm{Xj}=$ coefficient of change in decision making or activities that will be found

Aij $=$ technology coefficient of change in constraints $-\mathrm{i}$.

$\mathrm{bij}=$ limited resources that limit related activities or businesses are constanta or right value of constraints $-\mathrm{i}$

Optimization problems of distribution channels were formulated into Linear Programming model by determining preceded decision variables.

\section{Research Method}

Data were processed through qualitative and quantitative methods. Qualitative analysis was needed to observe distribution cost, the amount of demand, and available supply. Data obtained was formulated in transportation model and processed to be some activities, which will put into Linear Programming. Further, equality and inequality were processed in computer by using a LINDO (Linear Interactive Discrete Optimizer) software program.

Quantitative approach is done by choosing randomly and structured. Samples must be representative of the population, where the conclusions from data collection to obtain statistical calculations. 


\section{Research Findings and Discussions}

Linear Programming is chosen to solve problems in optimizing demand and supply allocation to achieve optimal marketing level and to discover optimal distribution that will maximize profit. Based on that method, primal analysis, dual analysis, and sensitivity analysis are conducted.

Dual analysis is done to discover either rare or frequent resources in production process. Sensitivity analysis is linked with the change of discrete parameter to observe the change that can be tolerated before optimal solution losses its optimization.

Distribution system in PT Frisian Flag Indonesia is indirect distribution. PT Frisian Flag Indonesia uses intermediary company, namely Yap Cwee Hock (YCH) as Main Distribution Center (MDC). According to level of distribution channel, PT Frisian Flag Indonesia uses distribution channels of Producer-Distributor Industry-Customer, illustrated as follows:

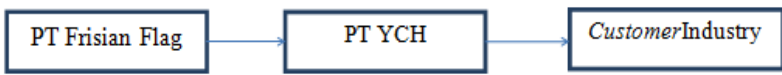

Figure 1. Level of Distribution Channel in PT Frisian Flag Indonesia

Transportation model of milk products in PT Frisian Flag Indonesia consists of objective function and some constraints, as follows:

1. Objective Function (Minimized Cost)

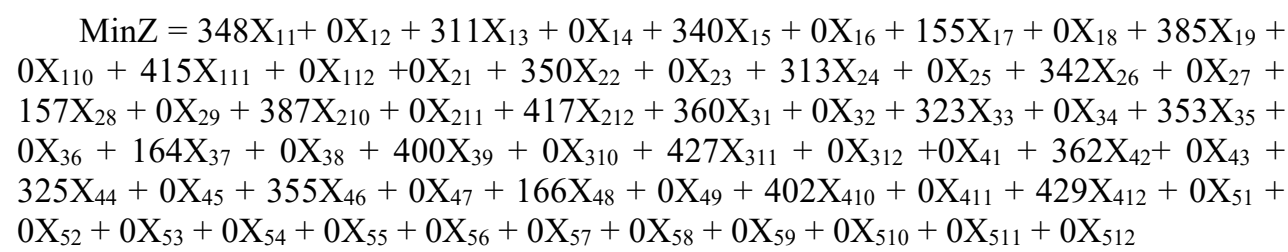

2. Constraints

1) Constraints of Supply in Pasar Rebo

$\mathrm{X}_{11}+\mathrm{X}_{12}+\mathrm{X}_{13}+\mathrm{X}_{14}+\mathrm{X}_{15}+\mathrm{X}_{16}+\mathrm{X}_{17}+\mathrm{X}_{18}+\mathrm{X}_{19}+\mathrm{X}_{110}+\mathrm{X}_{111}+\mathrm{X}_{112}<=19282$

2) Constraints of Supply in Ciracas

$\mathrm{X}_{21}+\mathrm{X}_{22}+\mathrm{X}_{23}+\mathrm{X}_{24}+\mathrm{X}_{25}+\mathrm{X}_{26}+\mathrm{X}_{27}+\mathrm{X}_{28}+\mathrm{X}_{29}+\mathrm{X}_{210}+\mathrm{X}_{211}+\mathrm{X}_{212}<=33024$

3) Constraints of Supply in MDC Cibitung for powdered milk

$\mathrm{X}_{31}+\mathrm{X}_{32}+\mathrm{X}_{33}+\mathrm{X}_{34}+\mathrm{X}_{35}+\mathrm{X}_{36}+\mathrm{X}_{37}+\mathrm{X}_{38}+\mathrm{X}_{39}+\mathrm{X}_{310}+\mathrm{X}_{311}+\mathrm{X}_{312}<=175048$

4) Constraints of Supply in MDC Cibitung for condensed milk

$\mathrm{X}_{41}+\mathrm{X}_{42}+\mathrm{X}_{43}+\mathrm{X}_{44}+\mathrm{X}_{45}+\mathrm{X}_{46}+\mathrm{X}_{47}+\mathrm{X}_{48}+\mathrm{X}_{49}+\mathrm{X}_{410}+\mathrm{X}_{411}+\mathrm{X}_{412}=541460$

5) Constraints of Dummy Sources

$\mathrm{X}_{51}+\mathrm{X}_{52}+\mathrm{X}_{53}+\mathrm{X}_{54}+\mathrm{X}_{55}+\mathrm{X}_{56}+\mathrm{X}_{57}+\mathrm{X}_{58}+\mathrm{X}_{59}+\mathrm{X}_{510}+\mathrm{X}_{511}+\mathrm{X}_{512}=19631$

6) Constraints of Demand in SP Medan for powdered milk

$\mathrm{X}_{11}+\mathrm{X}_{21}+\mathrm{X}_{31}+\mathrm{X}_{41}>=7098$

7) Constraints of Demand in SP Medan for condensed milk $\mathrm{X}_{12}+\mathrm{X}_{22}+\mathrm{X}_{32}+\mathrm{X}_{42}>=19512$

8) Constraints of Demand in SP Semarang for powdered milk $\mathrm{X}_{13}+\mathrm{X}_{23}+\mathrm{X}_{33}+\mathrm{X}_{43}>=2738$

9) Constraints of Demand in SP Semarang for condensed milk $\mathrm{X}_{14}+\mathrm{X}_{24}+\mathrm{X}_{34}+\mathrm{X}_{44}>=7529$ 
10) Constraints of Demand in SP Surabaya for powdered milk $\mathrm{X}_{15}+\mathrm{X}_{25}+\mathrm{X}_{35}+\mathrm{X}_{45}>=22246$

11) Constraints of Demand in SP Surabaya for condensed milk $\mathrm{X}_{16}+\mathrm{X}_{26}+\mathrm{X}_{36}+\mathrm{X}_{46}>=55675$

12) Constraints of Demand in Modern Trade for powdered milk $\mathrm{X}_{17}+\mathrm{X}_{27}+\mathrm{X}_{37}+\mathrm{X}_{47}>=11913$

13) Constraints of Demand in Modern Trade for condensed milk $\mathrm{X}_{18}+\mathrm{X}_{28}+\mathrm{X}_{38}+\mathrm{X}_{48}>=77392$

14) Constraints of Demand in General Trade 1 for powdered milk $\mathrm{X}_{19}+\mathrm{X}_{29}+\mathrm{X}_{39}+\mathrm{X}_{49}>=124082$

15) Constraints of Demand in General Trade 1 for condensed milk $\mathrm{X}_{110}+\mathrm{X}_{210}+\mathrm{X}_{310}+\mathrm{X}_{410}>=346727$

16) Constraints of Demand in General Trade 2 for powdered milk $\mathrm{X}_{111}+\mathrm{X}_{211}+\mathrm{X}_{311}+\mathrm{X}_{411}>=30809$

17) Constraints of Demand in General Trade 2 for condensed milk= $\mathrm{X}_{112}+\mathrm{X}_{212}+\mathrm{X}_{312}+\mathrm{X}_{412}>=82724$

$$
\begin{aligned}
& X 11>=0 \times 21=0 \times 31>=0 \times 41>=0 \\
& X 12=0 \times 22>=0 \times 32>=0 \times 42>=0 \\
& X 13>=0 \times 23=0 \times 33>=0 \times 43>=0 \\
& X 14=0 \times 24>=0 \times 34>=0 \times 44>=0 \\
& X 15>=0 \times 25=0 \times 35>=0 \times 45>=0 \\
& X 16=0 \times 26>=0 \times 36>=0 \times 46>=0 \\
& X 17>=0 \times 27=0 \times 37>=0 \times 47>=0 \\
& X 18=0 \times 28>=0 \times 38>=0 \times 48>=0 \\
& X 19>=0 \times 29=0 \times 39>=0 \times 49>=0 \\
& X 110=0 \times 210>=0 \times 310>=0 \times 410>=0 \\
& X 111>=0 \times 211=0 \times 311>=0 \times 411>=0 \\
& X 112=0 \times 212>=0 \times 312>=0 \times 412>=0
\end{aligned}
$$

Coefficient in each variable is distribution cost per unit (ton) for each variable that has to be paid to distribute milk from plant sources to various destinations. In Variable $\mathrm{X}_{31}$, the cost needed is 360 , which means that product transportation from MD source to Supply Point Medan for powdered milk is Rp 360,000 per ton.

The Results of primal analysis, dual analysis, and sensitivity analysis lead to the difference of actual circumstance with optimal circumstance in distribution channel of Frisian Flag Indonesia, which illustrated in Fig 2 and Fig 3:

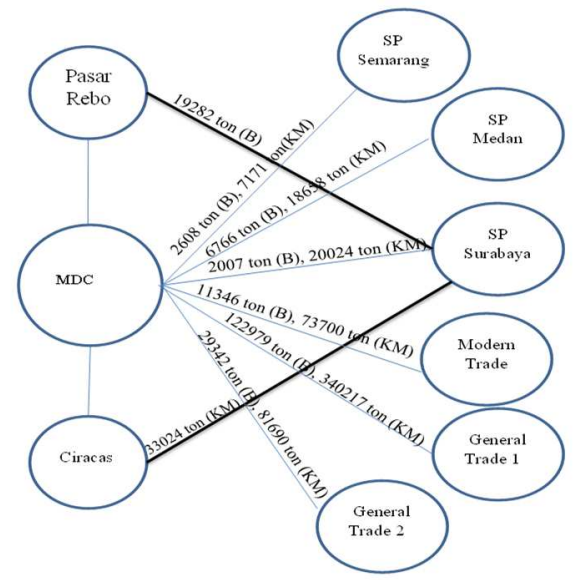


Figure 2. Distribution Channel and Actual Product Volume

In actual circumstance, Plant Pasar Rebo and Plant Ciracas distribute19,282 tons powdered milk and 33,024 tons condensed milk to Supply Point Surabaya.

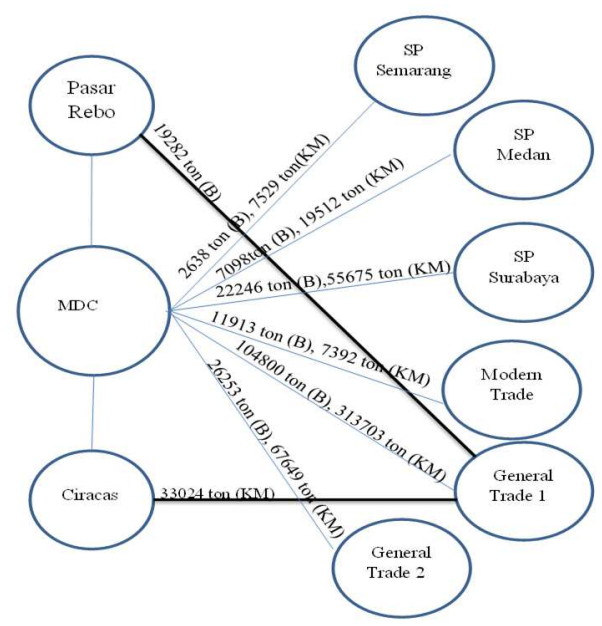

Figure 3. Distribution Channel and Optimal Product Volume

In optimal circumstance, 19,282 tons of powdered milk and 33,042 tons of condensed milk are distributed from Plant Pasar Rebo to General Trade 1. In optimal circumstance, Plant Surabaya receives 22,246 tons of powdered milk and 55,675 tons of condensed milk. It is different with actual circumstance where SP Surabaya received powdered and condensed milk from 3 sources. It is caused by the difference of total cost that will be paid.

The difference between actual distribution and optimal distribution in area from MDC to Supply Point Medan is 332 tons of powdered and 854 tons of condensed milk. There is allocation difference in Supply Point Semarang, i.e. 130 tons of powdered milk and 358 tons of condensed milk. There is distribution allocation difference in Modern Trade, i.e. 567 tons of powdered milk and 3692 tons of condensed milk. Meanwhile, there is lack of distribution to General Trade 1, i.e. 18,719 tons of powdered milk and 25,514 tons of condensed milk.

Total product difference leads to cost difference. Total cost in actual circumstance is $\mathrm{Rp}$ $285,663,972,000$ while in optimal circumstance total cost is $\mathrm{Rp} 293,832,106,000$, so there is $\mathrm{Rp} 1,831,866,000$ cost difference. The difference is caused by the difference of milk product allocation that is distributed from areas to various destinations. 


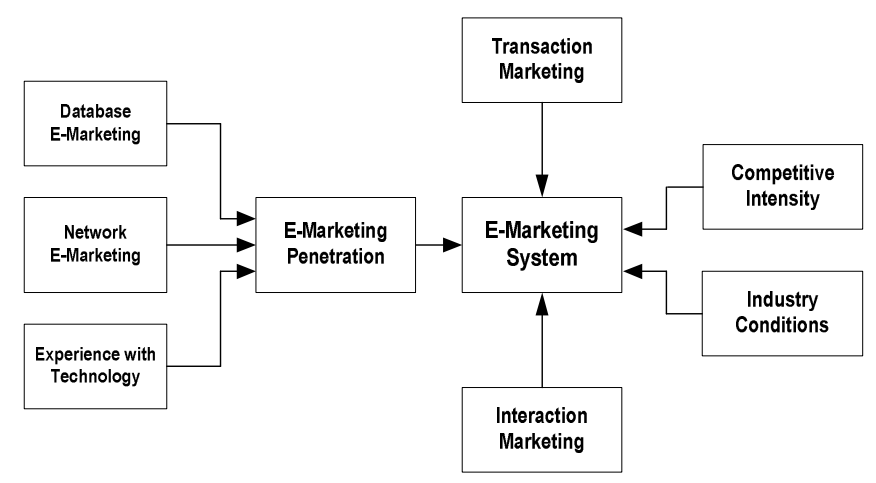

Figure 4. Proposed Model

These data procedures have been used in past surveys and have been shown to be effective ways of collecting research data about firm practices [8].

Based on research previously that Database Marketing and Network Marketing were found to be antecedents to e-Marketing. E-Marketing and Transaction Marketing were found to be positively associated with o performance.

In testing the robustness of the proposed model, we first tested whether Database Marketing and Network Marketing directly influence performance rather than being mediated via e-Marketing.

\section{Conclusions}

1. Distribution channel used by PT Frisian Flag Indonesia is indirect distribution. PT Frisian Flag Indonesia uses intermediary company, namely PT Yap Cwee Hock $(\mathrm{YCH})$ as Main Distribution Center (MDC).

2. Plant Pasar Rebo and Plant Ciracas distribute their products to General Trade 1 for distribution allocation in optimal circumstance, i.e. 19,282 tons of powdered milk and 33,024 tons of condensed milk. Meanwhile, other destinations receive all products only from MDC and it leads to increasing product. However, total product that will be distributed to General Trade 2 is decreasing, i.e. 3,089 tons of powdered milk so that milk distributed is 26,253 tons. Total product of condensed milk is decreasing, i.e. 14,041 tons so milk distributed is 67,647 tons.

3. Distribution costs include some costs, such as transportation cost, handling cost, porter cost, etc. Total cost that has to be paid by PT Frisian Flag Indonesia in actual circumstance is $\mathrm{Rp} 285,663,972,000$, while total cost in optimal circumstance is $\mathrm{Rp}$ $283,832,106,000$. There is the difference of total distribution cost that has to be paid. This circumstance leads to the difference between actual and optimal circumstance, i.e. $\mathrm{Rp} 1,831,866,000$ due to the difference of product volume distributed between actual and optimal circumstance.

\section{Suggestion}


1. An observation on distribution channel is necessary to consider total cost that has to be paid. According to research result through Linear Programming, Plant Pasar Rebo and Plant Ciracas distribute the products to General Trade 1 instead of Supply Point Surabaya.

2. Further research has to be conducted to study other factors that cause the difference of distribution of Frisian Flag milk from each area to each destination.

\section{References}

[1] Center for Agriculture Data and Information System, Statistic of Agricultural Land 2008-2013, Secretariat General of Ministry of Agriculture, Jakarta, Indonesia, 2013.

[2] Tjiptono, Fandy. Strategi Pemasaran. Edisi Ketiga. Andi Publisher. Yogyakarta 2006.

[3] Kotler, Philip Manajemen Pemasaran: Analisis Perencanaan. Implementasi dan Kontrol Jilid 2. [translation]. Prenhalindo. Jakarta 2000.

[4] Watson, R.P., Leyland, F.P., Berthon, P. and Zinkham, G, "U-commerce: expanding theuniverse of marketing”,Journal of the Academy of Marketing Science, Vol. 30 No. 4,pp. 333-47 (2002) [accessed Nov 29 2018].

[5] Aminudin. 2005. Prinsip-Prinsip Riset Operasi. Erlangga. Jakarta

[6] Sumarni, Murti dan Soeprihanto, John. 1993. Pengantar Bisnis: Dasar-Dasar Ekonomi Perusahaan. Edisi Ketiga. Liberty Yogyakarta. Yogyakarta.

[7] Nasendi, B.D dan A.Anwar. Program Linear dan Variasinya. PT Gramedia. Jakarta 1985.

[8] Wijaya, Andi. Pengantar Riset Operasi Edisi Ketiga. Mitra Wacana Media. Jakarta 2012.

[9] Neelankavil, J. P., Mathur, A., \& Zhang, Y. Determinants of Managerial Performance: A CrossCultural Comparison of the Perceptions of Middle-Level Managers in Four Countries. Journal of International Business Studies, 31(1), 121-140 (2000). 